\title{
Human chorionic gonadotropin (hCG) $\beta$-core fragment is produced by degradation of hCG or free hCG $\beta$ in gestational trophoblastic tumors: a possible marker for early detection of persistent postmolar gestational trophoblastic disease
}

\author{
T Okamoto, K Matsuo ${ }^{1}$, R Niu' ${ }^{2}$, M Osawa and H Suzuki ${ }^{1}$ \\ Department of Obstetrics and Gynecology, Chukyo Hospital, Nagoya, Japan \\ ${ }^{1}$ Tsukuba Research Laboratory, Toagosei Co. Ltd, Tsukuba, Japan \\ ${ }^{2}$ Department of Obstetrics and Gynecology, Nagoya University School of Medicine, Nagoya, Japan \\ (Requests for offprints should be addressed to T Okamoto, Department of Obstetrics and Gynecology, Chukyo Hospital, 1-1-10, Sanjo, Minami-ku, \\ Nagoya 457-8510, Japan; Email: kmottm8@hotmail.com)
}

\begin{abstract}
The present study was undertaken to investigate whether human chorionic gonadotropin (hCG) $\beta$-core fragment (hCG $\beta c f)$ was directly produced by gestational trophoblastic tumors. Immunoreactivity of hCG $\beta$ cf was demonstrated in the extracts as well as in the culture media of hydatidiform mole tissues. It was also present in the extracts of choriocarcinoma tissues, and its molar concentration exceeded that of intact hCG. The presence of hCG $\beta c f$ was then confirmed by gel chromatography and Western blot analysis. Immunohistochemistry showed localization of hCG $\beta c f$ immunoreactivity to the syncytiotrophoblasts and scattered cells in the stroma of mole tissue, and to syncytiotrophoblastic cells in choriocarcinoma. Immunoreactivity of hCG $\beta c f$ was also detected in the sera of the patients with gestational trophoblastic disease,
\end{abstract}

although the hCG $\beta \mathrm{cf} / \mathrm{hCG}$ ratio was less than one hundredth of that in the tissue extracts. Serial measurement of serum hCG $\beta$ cf levels after mole evacuation showed that they declined much more rapidly than those of hCG and became undetectable in the patients with subsequent spontaneous resolution, while hCG $\beta c f$ remained or became detectable before the rise of hCG was observed in the patients with subsequent persistent trophoblastic disease. Taken together, these results suggest that hCG $\beta c f$ is directly produced by gestational trophoblastic tumors, and monitoring of hCG $\beta c f$ in the serum after mole evacuation may be useful for early prediction of subsequent development of postmolar persistent trophoblastic disease.

Journal of Endocrinology (2001) 171, 435-443

\section{Introduction}

Gestational trophoblastic disease (GTD) refers to a wide spectrum of diseases ranging from benign hydatidiform mole to highly malignant choriocarcinoma and placental site trophoblastic tumor. Hydatidiform mole is a specific form of abnormal pregnancy that is characterized by the presence of hydropic swelling of the chorionic villi and proliferation of the trophoblasts. It is associated with a substantial risk (5-10\%) of subsequent persistent GTD and may eventually develop into choriocarcinoma (Lurain et al. 1983). Except for the serial measurement of human chorionic gonadotropin (hCG), there is no reliable predictor for the early detection of persistent GTD.

The hCG $\beta$-subunit core fragment (hCG $\beta \mathrm{cf}$ ) is a form of hCG $\beta$ composed of segments of hCG $\beta$ residues $6-40$ disulfide-linked to residues 55-92 and lacking the hCG $\beta$ carboxy-terminal immunological determinant; it has a molecular mass of approximately 12 000-17 000 (Birken et al. 1988, Blithe et al. 1988). hCG $\beta c$ is quantitatively the major form of immunoreactive hCG molecules in pregnancy urine, the concentration of which is 2 to10 times higher than that of intact hCG on a molar basis (Kato \& Braunstein 1988, Wehmann et al. 1990, de Medeiros et al. 1992), and it has been assumed that hCG $\beta c f$ originates from the renal metabolism of intact hCG or free hCG $\beta$ (Wehmann \& Nisula 1980, Lefort et al. 1984, 1986). However, in a study involving the intravenous injection of recombinant hCG into healthy, non-pregnant women, the hCG $\beta c f$ measured in urine was only $12 \cdot 2 \%$ of the amount of hCG excreted in urine, and it was suggested that there may be more than one pathway responsible for the production of hCG $\beta$ cf in pregnancy (Norman et al. 2000). In fact, placental tissue has been associated with the production of hCG $\beta c f$ (Cole \& Birken 1988, Udagawa et al. 1998). Moreover, we recently demonstrated that hCG $\beta$ cf was directly produced by cancer cells in vitro, including choriocarcinoma cell lines (Okamoto et al. 
2001). Also in that report, we detected hCG $\beta$ cf immunoreactivity in the serum of the mice transplanted with choriocarcinoma cells that produced hCG $\beta$ cf in vitro. In view of these observations, the present study was undertaken to investigate the presence of hCG $\beta c f$ in the tissue specimens of hydatidiform mole and choriocarcinoma. Serum levels of hCG $\beta c f$ in the patients with GTD were also determined.

\section{Materials and Methods}

Tissue and blood sample collection

Tissue samples were obtained from 10 patients with complete hydatidiform mole (9 to 14 weeks of gestation) and 5 patients with gestational choriocarcinoma; all were histologically confirmed and none of them had been treated with chemotherapy. They were collected immediately after delivery or at the time of surgery, snap frozen in liquid nitrogen and stored at $-80{ }^{\circ} \mathrm{C}$. Fresh molar tissue was also used for organ culture. Some of the samples were fixed by immersion in 10\% neutral buffered formalin for 12-24 h and processed for paraffin embedding by the standard methods.

Serum samples were obtained from 14 patients with complete hydatidiform mole, 4 of whom developed persistent GTD, and 4 patients with gestational choriocarcinoma. The 4 patients who developed postmolar persistent GTD were diagnosed as 'clinical invasive mole' on the basis that in weekly measurements of serum hCG levels there were two consecutive rising levels or levels reached a plateau for three or more consecutive weeks, combined with the 'choriocarcinoma diagnostic score', which is routinely used in Japan (Okamoto et al. 1998). The samples were stored at $-80^{\circ} \mathrm{C}$ until use.

Written informed consent for the collection of tissue and serum samples was obtained from all patients, and the study was conducted in accordance with the institutional guidelines.

\section{Organ culture of molar tissue}

Organ culture of molar tissue was performed by the method described previously (Udagawa et al. 1998). Briefly, pieces of molar vesicles were rinsed in phosphatebuffered saline (PBS) and cultured in a six-well TranswellCOL chamber (Coster, Cambridge, MA, USA). Incubation was carried out in the culture medium (Dulbecco's Minimal Essential Medium supplemented with $10 \%$ fetal calf serum) at $37^{\circ} \mathrm{C}$ in humidified $5 \%$ $\mathrm{CO}_{2}$. The culture media were harvested $0 \cdot 5,1,1 \cdot 5,2,4$, or $24 \mathrm{~h}$ later for the measurement of intact hCG, free hCG $\beta$ and hCG $\beta c f$. Each experiment was performed in triplicate.

Tumor formation of choriocarcinoma cells injected into the nude mouse

The NaUCC-3 choriocarcinoma cell line, which was established and maintained in our department (Sugiura et al. 1988), was cultured in RPMI 1640 supplemented with $10 \%$ fetal calf serum in a humidified atmosphere of $5 \% \mathrm{CO}_{2}$ at $37^{\circ} \mathrm{C}$. Six-week-old female BALB/c nu/nu mice (obtained from Clea Japan Animals Inc, Tokyo, Japan) were injected with $1 \times 10^{6} \mathrm{NaUCC}-3$ cells subcutaneously in the flank. After tumor formation, the mice were killed, and the tumors were excised and snap frozen. The tumors were histologically proven to be choriocarcinomas (Okamoto et al. 2001).

\section{Preparation of tissue extracts}

The frozen tissue samples were homogenized with a motor-driven Teflon pestle for $10 \mathrm{~min}$ on ice in $1 \mathrm{ml}$ extraction buffer (150 mM NaCl, $20 \mathrm{mM}$ Tris ( $\mathrm{pH} 7 \cdot 5$ ), $5 \mathrm{mM}$ EDTA, $1 \%$ Nonidet P-40 containing $1 \mathrm{mM}$ phenylmethylsulfonyl fluoride and $2 \mu \mathrm{g} / \mathrm{ml}$ aprotinin) per $100 \mathrm{mg}$ tissue wet weight, and the tissue extracts were obtained after centrifugation at 15000 r.p.m. for $20 \mathrm{~min}$ at $4{ }^{\circ} \mathrm{C}$.

\section{Determination of intact $h C G$, free $h C G \beta$, and $h C G \beta c f$}

Levels of intact hCG, free hCG $\beta$, and hCG $\beta$ cf were determined by the enzyme immunoassays (EIAs) described elsewhere (Udagawa et al. 1998). The EIA for hCG $\beta$ cf gave negligible cross-reactivity with intact hCG $(0.034 \%)$ or free hCG $\beta(0.12 \%)$, but the results for hCG $\beta c f$ were always corrected for cross-reaction with these molecules. Occasionally, the concentration of each molecule was calculated and compared on a molar basis, assuming that the molecular mass of hCG $\beta$ cf is 15000 (Birken et al. 1988).

\section{Chromatography of the tissue extract}

Tissue extracts of a mole and a choriocarcinoma were analyzed by chromatography on Superdex 75 (Pharmacia Biotech, Uppsala, Sweden). Aliquots $(200 \mu \mathrm{l})$ of each sample were applied to a $1 \times 30 \mathrm{~cm}$ column bed equilibrated with $50 \mathrm{mM}$ sodium phosphate buffer containing $0 \cdot 15 \mathrm{M} \mathrm{NaCl}$ and $0.02 \%$ sodium azide $(\mathrm{pH} 7 \cdot 0)$. The flow rate of the column was adjusted to $0.5 \mathrm{ml} / \mathrm{min}$, and $0.5 \mathrm{ml}$ fractions were collected by gravity at $4{ }^{\circ} \mathrm{C}$. Each fraction was measured for intact hCG, free hCG $\beta$ or hCG $\beta$ cf by the respective EIAs, and the data were calibrated on molecular size.

\section{Western blot analysis}

SDS-PAGE for immunoblotting was performed in 10\% acrylamide slab gels under non-reducing conditions. Protein molecular weight standards (Kaleidoscope Prestained Standards; Bio-Rad Laboratories, Hercules, CA, USA) were used to calibrate the gels. Proteins were transferred to nitrocellulose membranes (Amersham, Aylesbury, 
Table 1 Amounts of hCG, free hCG $\beta$, and hCG $\beta$ cf in the culture media of molar tissue. All experiments were performed in triplicate, and values are expressed as the mean \pm S.D. (pmol/g tissue/4 h)

\begin{tabular}{|c|c|c|c|c|c|}
\hline & hCG & Freeß & hCG $\beta c f$ & $\begin{array}{l}\text { Freeß/hCG } \\
(\%)\end{array}$ & $\begin{array}{l}\text { hCGßcf/hCG } \\
(\%)\end{array}$ \\
\hline \multicolumn{6}{|c|}{ Sample } \\
\hline 1 & $3720 \pm 470$ & $195 \pm 33$ & $177 \pm 5 \cdot 8$ & $5 \cdot 2$ & $4 \cdot 8$ \\
\hline 2 & $22200 \pm 3950$ & $377 \pm 31$ & $586 \pm 10 \cdot 4$ & $1 \cdot 7$ & $2 \cdot 6$ \\
\hline 3 & $10200 \pm 2570$ & $244 \pm 44$ & $1370 \pm 360$ & $2 \cdot 4$ & $13 \cdot 4$ \\
\hline 4 & $3840 \pm 524$ & $343 \pm 39$ & $1347 \pm 387$ & $8 \cdot 9$ & $35 \cdot 1$ \\
\hline 5 & $2980 \pm 151$ & $280 \pm 84$ & $1360 \pm 163$ & $9 \cdot 4$ & $45 \cdot 6$ \\
\hline 6 & $4570 \pm 672$ & $275 \pm 40$ & $1640 \pm 169$ & $6 \cdot 0$ & $35 \cdot 9$ \\
\hline 7 & $3220 \pm 495$ & $321 \pm 59$ & $1210 \pm 410$ & $10 \cdot 0$ & $37 \cdot 6$ \\
\hline 8 & $2930 \pm 392$ & $282 \pm 36$ & $820 \pm 240$ & $9 \cdot 6$ & $28 \cdot 0$ \\
\hline 9 & $950 \pm 120$ & $54 \pm 20$ & $99 \pm 7 \cdot 7$ & $5 \cdot 7$ & $10 \cdot 4$ \\
\hline 10 & $814 \pm 148$ & $140 \pm 33$ & $334 \pm 67$ & $17 \cdot 2$ & $41 \cdot 0$ \\
\hline
\end{tabular}

Bucks, UK) and blocked overnight at $4{ }^{\circ} \mathrm{C}$ in $10 \%$ skimmed milk in TBST buffer $(10 \mathrm{mM}$ Tris- $\mathrm{HCl}, \mathrm{pH}$ $8 \cdot 0,150 \mathrm{mM} \mathrm{NaCl}$, and $0 \cdot 1 \%$ Tween 20). The membranes were incubated with B210 monoclonal antibody, which is highly specific to hCG $\beta$ cf (Krichevsky et al. 1991) at a concentration of $50 \mu \mathrm{g} / \mathrm{ml}$ for $2 \mathrm{~h}$ at room temperature. After washing with TBST, biotinylated goat anti-mouse immunoglobulin G (IgG) (DAKO, Glostrup, Denmark) was added. Positive bands were visualized by an enhanced chemiluminescence detection system (ECL; Amersham) and exposure to Hyperfilm (Amersham).

\section{Immunohistochemical study}

Formalin-fixed, paraffin-embedded tissue sections were deparaffinized in xylene, and hydrated through a descending series of ethanol. They were blocked with normal goat serum, incubated with B210 monoclonal antibody, and then further incubated with biotinylated goat antimouse IgG (Vector, Peterborough, UK). Avidin-biotinperoxidase complex (Vector) was applied, and visualization was carried out with a peroxidase solution containing $0.02 \%$ hydrogen peroxide and $0.1 \% \quad 3,3^{\prime}-$ diaminobenzidine-tetrahydrochloride (Merck, Darmstadt, Germany) in PBS. Sections were counterstained with hematoxylin. Control mouse IgG1 obtained from a nonimmunized mouse was used, instead of the primary antibody, as a negative control. Also, specificity of the primary antibody was verified by the absence of staining when reacted with the primary antibody preabsorbed with an excess of hCG $\beta$ cf.

\section{Statistical analysis}

Statistical analysis was performed using Wilcoxon signedranks test or Mann-Whitney $U$ test. Significance was set at $P<0 \cdot 05$.

\section{Results}

Presence of hCG $\beta$ cf immunoreactivity in the culture media and tissue extracts

Levels of intact hCG, free hCG $\beta$, and hCG $\beta$ cf were examined in the culture media of hydatidiform mole tissues. First, a time course study was carried out, and a representative result is presented in Fig. 1. Immunoreactivity of each molecule appeared as early as $30 \mathrm{~min}$ after the start of incubation, and increased until $4 \mathrm{~h}$, after which it reached a plateau. Interestingly, a rise in hCG $\beta \mathrm{cf}$ appeared later than that of intact hCG. Then, the amounts of each molecule in the culture media (4-h incubation) were determined using 10 hydatidiform mole samples (Table 1). Immunoreactivity of hCG $\beta c f$ was present in the culture media at levels from $2 \cdot 6 \%$ to $45 \cdot 6 \%$ (mean \pm s.D.,

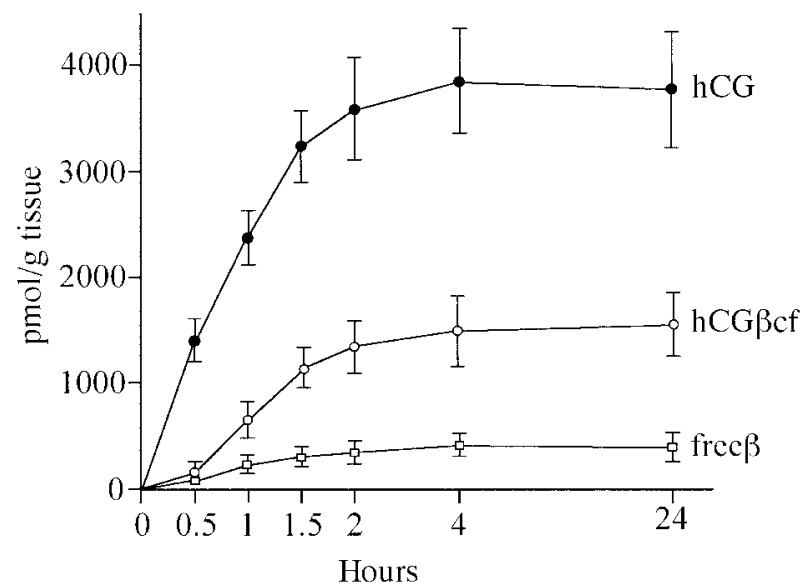

Figure 1 Presence of hCG $\beta c f$ immunoreactivity in the culture media of molar tissue. Molar tissue (sample no. 4 in Table 1) was cultured for $0 \cdot 5,1,1 \cdot 5,2,4$, or $24 \mathrm{~h}$ in triplicate. Values represent the means \pm S.D. 
Table 2 Amounts of hCG, free hCG $\beta$, and hCG $\beta$ cf in the extracts of mole and choriocarcinoma tissues. The sample numbers of mole tissue correspond to those in Table 1. All experiments were performed in triplicate, and values are expressed as the mean \pm S.D. (pmol/g tissue)

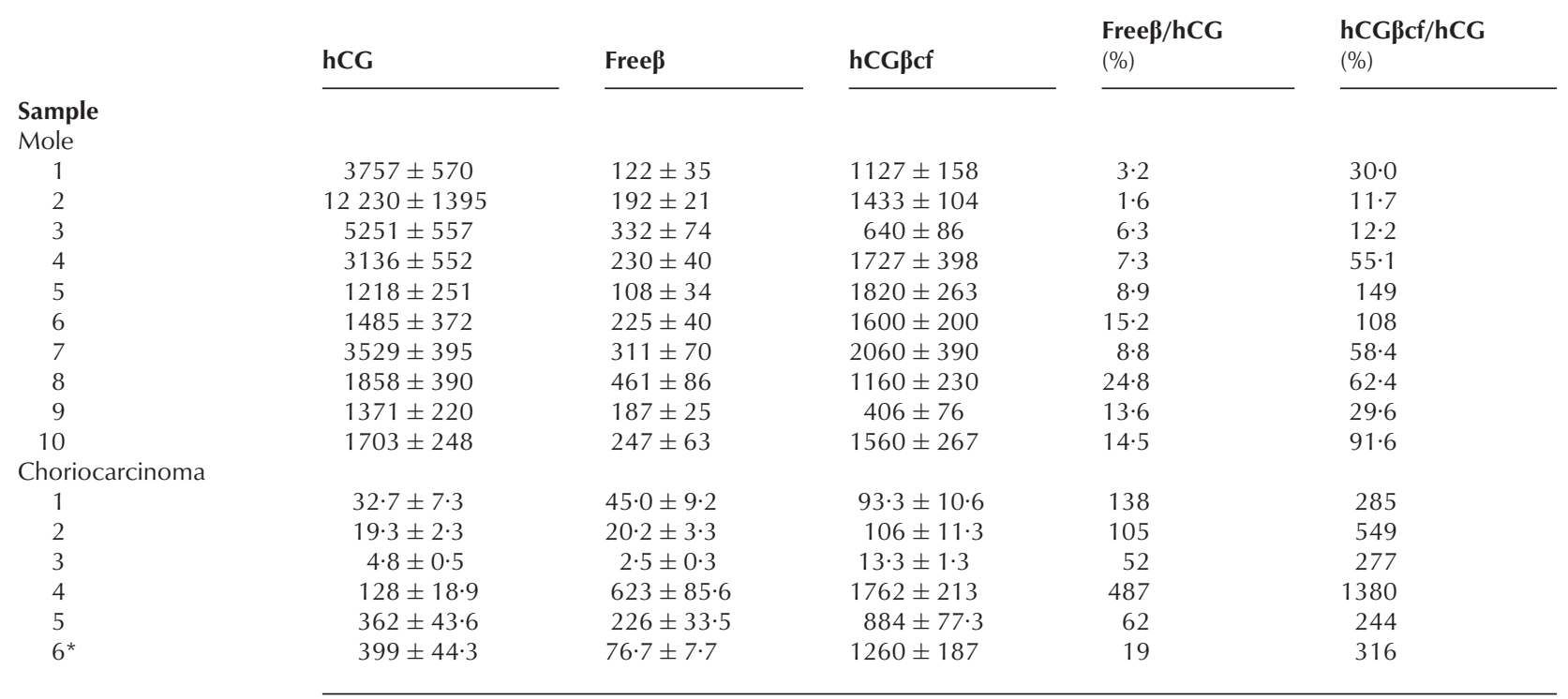

*Tumor specimen formed by the inoculation of NaUCC-3 choriocarcinoma cells into a nude mouse.

$25 \cdot 4 \% \pm 16 \cdot 1 \%$ ) of that of intact $\mathrm{hCG}$, and it exceeded that of free hCG $\beta$ except for one sample.

The amounts of immunoreactivity of intact hCG, free hCG $\beta$, and hCG $\beta$ cf in the extracts of hydatidiform mole and choriocarcinoma tissues are presented in Table 2 . In the molar tissues, immunoreactivity of hCG $\beta$ cf was $11 \cdot 7 \%$ to $149 \%$ (mean \pm S.D., $60 \cdot 8 \% \pm 44 \cdot 3 \%$ ) of that of intact hCG, which was significantly higher than that in the culture media of molar tissues (Wilcoxon signed-ranks test, $P=0.0069)$. On the other hand, no significant difference in the ratio of free hCG $\beta$ to intact $\mathrm{hCG}$ was observed between the culture media $(1 \cdot 7 \%-17 \cdot 2 \%, 7 \cdot 6 \% \pm 4 \cdot 5 \%)$ and tissue extracts $(1 \cdot 6 \%-24 \cdot 8 \%, 10 \cdot 4 \% \pm 6 \cdot 8 \%)$ of molar tissues $(P=0.0925)$. In the choriocarcinoma tissues, the $\mathrm{hCG} \beta \mathrm{cf} / \mathrm{hCG}$ ratio was significantly elevated (mean \pm S.D., $509 \% \pm 441 \%$ ) as compared with that in the molar tissues (Mann-Whitney $U$ test, $P=0 \cdot 0022$ ). Likewise, the free $\beta / \mathrm{hCG}$ ratio was significantly higher in the choriocarcinoma tissues $(143 \% \pm 173 \%)$ than in the molar tissues $(10 \cdot 4 \% \pm 6 \cdot 8 \%)(P=0 \cdot 0022)$.

\section{Chromatography of the tissue extracts}

Tissue extracts of a mole and a choriocarcinoma were gel filtrated, and the eluent fractions were measured by the EIAs. The results are shown in Fig. 2. Intact hCG, free $\mathrm{hCG} \beta$, and hCG $\beta \mathrm{cf}$ were detected in the expected order of each molecule. The elution profiles indicated that the tissue extracts of GTD contained hCG $\beta c f$, and its quantity was greater than that of intact $\mathrm{hCG}$ on a molar basis.

\section{Western blot analysis}

To confirm the presence of hCG $\beta$ cf in the tissue extracts, immunoblot analysis was performed under non-reducing conditions using a tumor formed by the inoculation of NaUCC-3 choriocarcinoma cells into a nude mouse, in addition to tissue from a mole and a choriocarcinoma. An immunoreactive band with a molecular mass of approximately $15 \mathrm{kDa}$ was seen, as was observed in the standard urinary hCG $\beta$ cf (Fig. 3, arrow). Also, some faint bands with molecular masses of approximately $40-60 \mathrm{kDa}$ were observed.

\section{Immunohistochemical localization of $h C G \beta c f$ in hydatidiform mole and choriocarcinoma}

Intense immunoreactivity of hCG $\beta$ cf was demonstrated in the syncytiotrophoblast of hydatidiform mole (Fig. 4A). Scattered cells in the villous stroma also showed positive immunoreactivity for hCG $\beta$ cf. With respect to choriocarcinoma, the tissue showed the typical pathological appearance of choriocarcinoma comprising dimorphic populations of malignant cytotrophoblasts and syncytiotrophoblasts, the latter of which revealed positive immunoreactivity for hCG $\beta$ cf (Fig. 4B, arrows). None of the 

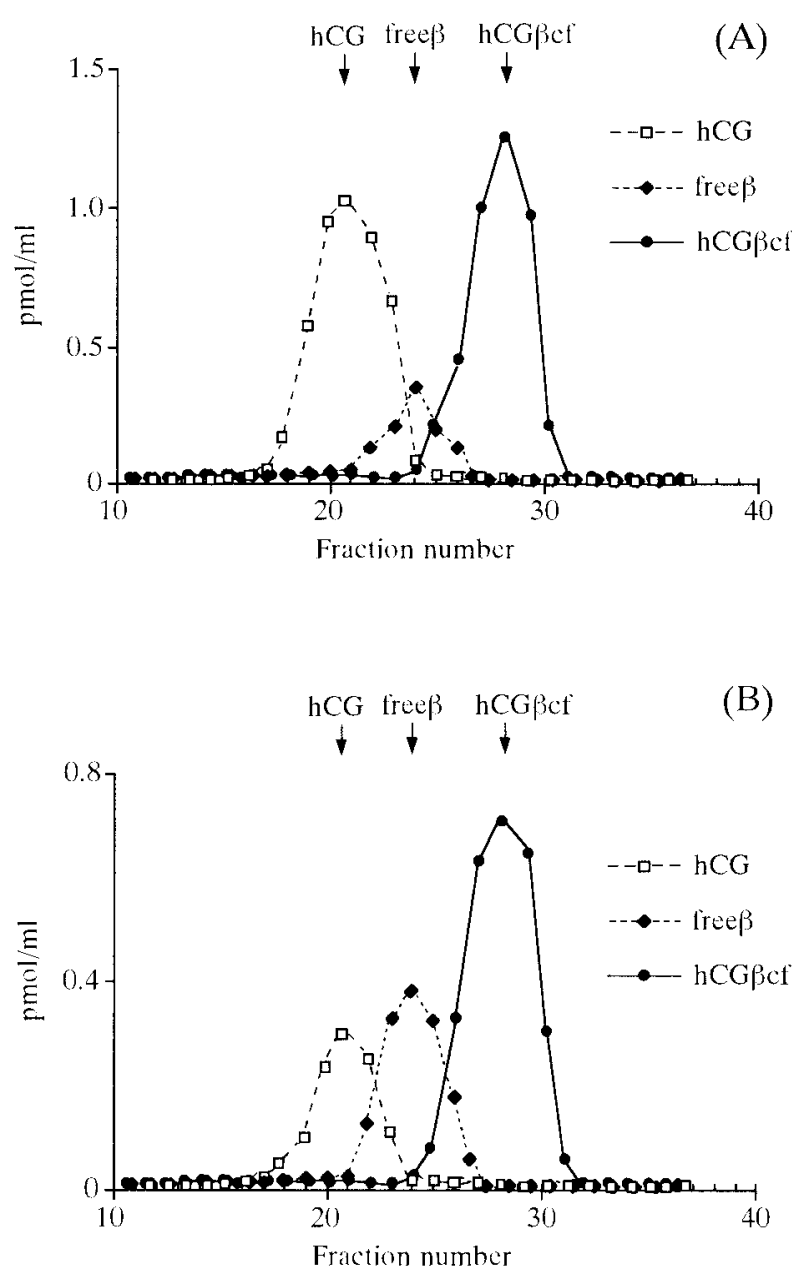

Figure 2 Elution profile of the tissue extracts by gel chromatography on Superdex 75. (A) Hydatidiform mole (sample no. 6 in Table 2). (B) Choriocarcinoma (sample no. 1 in Table 2). Elution fractions were assayed for intact hCG, free hCG $\beta$ and hCG $\beta c f$. The elution positions of the standard intact hCG, free hCG $\beta$ and hCG $\beta c f$ are indicated by the arrows.

control sections treated either with hCG $\beta$ cf-preincubated primary antibody (Fig. 4C and D) or with non-immune mouse IgG (data not shown) revealed any significant staining.

\section{Detection of $h C G \beta c f$ in the sera of patients with GTD}

Levels of immunoreactivity of intact hCG, free hCG $\beta$, and hCG $\beta c f$ in the sera of patients with GTD were measured. Not only intact hCG and free hCG $\beta$ but also hCG $\beta$ cf were present in their sera (Table 3). The hCG $\beta$ cf/hCG ratio was $0 \cdot 02 \%-0 \cdot 39 \%$ (mean \pm s.D., $0 \cdot 19 \% \pm 0 \cdot 10 \%)$ in hydatidiform mole, $0 \cdot 06 \%-0 \cdot 70 \%$ $(0 \cdot 41 \% \pm 0 \cdot 28 \%)$ in invasive mole, and $0.28 \%-1 \cdot 31 \%$ $(0 \cdot 84 \% \pm 0 \cdot 59 \%)$ in choriocarcinoma. Among these three groups, statistical significance was observed only between

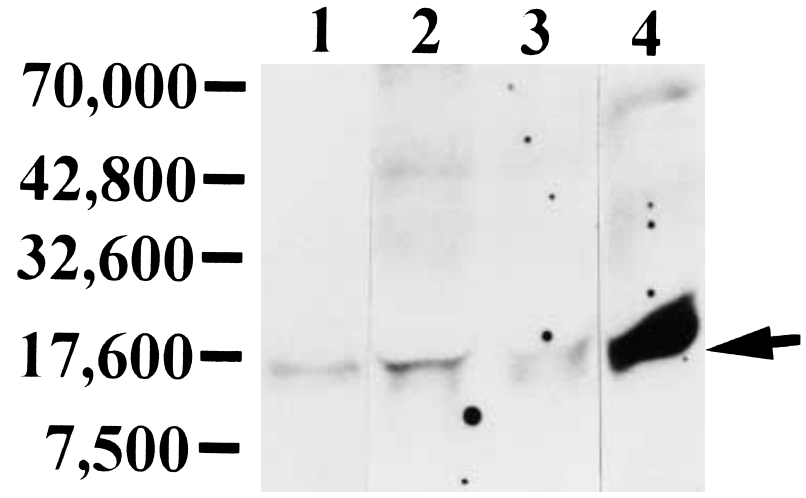

Figure 3 Immunoblots of the tissue extracts stained with B210 antibody under non-reducing conditions. Lane 1, standard urinary hCG $\beta \mathrm{cf}$ ( $2 \mathrm{ng} / \mathrm{ml}$; provided by Colombia University, NY, USA);

lane 2, hydatidiform mole; lane 3, choriocarcinoma; lane 4, tumor formed by the inoculation of NaUCC-3 choriocarcinoma cells into a nude mouse. The arrow indicates the position of major immunoreactivity of hCG $\beta c f$.

hydatidiform mole and choriocarcinoma $(P=0 \cdot 011)$. In the four patients who developed persistent GTD after uterine evacuation, the hCG $\beta c f / h C G$ ratio was higher, although not significantly so, than that prior to mole evacuation (patients $10-13$ in Table $3, P=0 \cdot 327$ ).

Serum levels of hCG $\beta c f$ were monitored in the patients with hydatidiform mole after uterine evacuation. In the cases with subsequent spontaneous remission, hCG $\beta \mathrm{cf}$ levels declined much more rapidly than those of hCG and became undetectable after evacuation (Fig. 5A). On the other hand, in the cases with subsequent persistent GTD, hCG $\beta c f$ remained or became detectable before the rise of hCG levels was observed (Fig. 5B), and it rapidly became undetectable after the initiation of chemotherapy. In the patients with choriocarcinoma, serum hCG $\beta$ cf levels were relatively low compared with those of the patients with hydatidiform mole, and they rapidly decreased and became undetectable after the initiation of chemotherapy (data not shown).

\section{Discussion}

hCG $\beta c f$ is the principal form of hCG $\beta$ subunit in pregnancy urine, and it has been generally assumed that it originates from the renal metabolism of intact hCG or free hCG $\beta$ (Birken et al. 1988, Wehmann et al. 1989, 1990, de Medeiros et al. 1992). However, we recently reported that hCG $\beta$ cf was directly produced not only by placental tissue (Udagawa et al. 1998) but also by cancer cells in vitro, including choriocarcinoma cell lines (Okamoto et al. 2001). As for trophoblastic disease, there are limited data describing hCG $\beta c f$ immunoreactivity in the tissue (Kardana et al. 1988, Khan et al. 2000), and the present study was performed to examine the presence and 


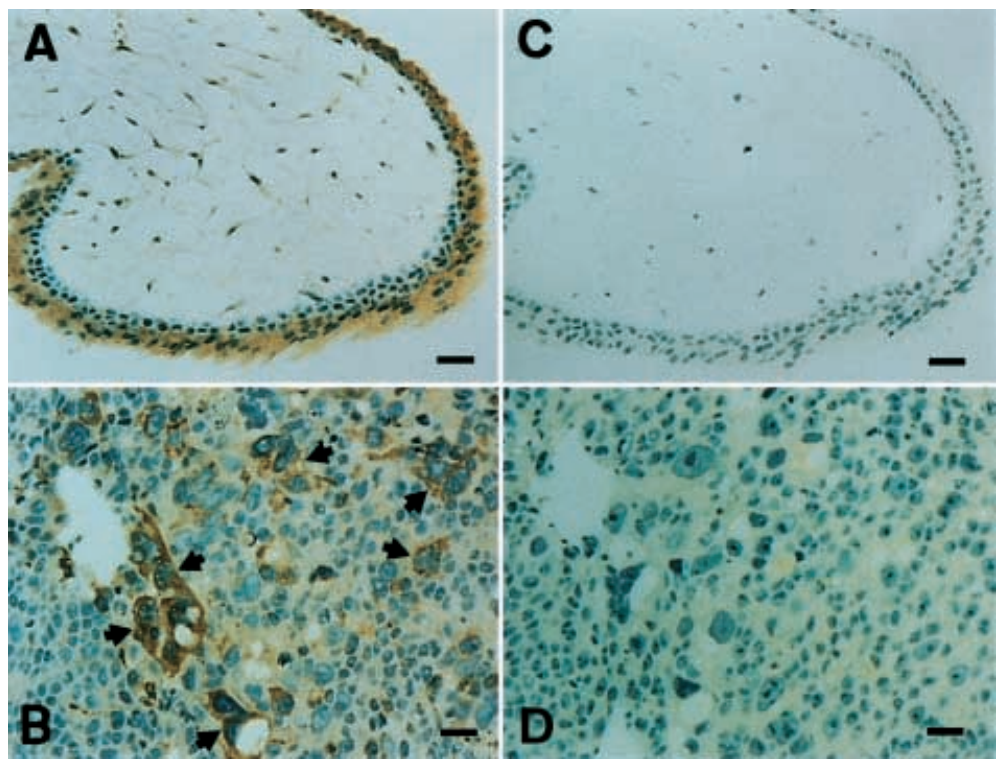

Figure 4 Immunohistochemical staining of hydatidiform mole and choriocarcinoma tissues with B210 antibody. (A) Hydatidiform mole. hCG $\beta$ cf immunoreactivity is prominent in the syncytiotrophoblast. Stromal cells are also positive for hCG $\beta c f$. Bar $=40 \mu \mathrm{m}$. (B) Choriocarcinoma. The tumor shows the typical dimorphic pattern of choriocarcinoma, and the syncytiotrophoblastic cells are positive for hCG $\beta c f$ (arrows). Bar $=40 \mu \mathrm{m}$. (C, D) Negative controls for A and B respectively in which the sections were treated with the primary antibody preincubated with an excess of hCG $\beta c f$.

production of hCG $\beta \mathrm{cf}$ in gestational trophoblastic tumors using clinical tissue specimens.

Immunoreactivity of hCG $\beta$ cf was detected in the culture media of hydatidiform mole tissues. It was also detectable in the tissue extracts of mole and choriocarcinoma. Then gel chromatography of the tissue extracts and Western blot analysis were performed, which showed that the hCG $\beta c f$ immunoreactive material was indistinguishable from hCG $\beta c f$ derived from pregnancy urine. Thus, it could be concluded that hCG $\beta$ cf is produced by mole and choriocarcinoma tissues, although there may exist some differences, such as that in carbohydrate moieties (de Medeiros et al. 1993), between hCG $\beta$ cf in pregnancy urine and that in trophoblastic tumors.

In the culture media of molar tissue, hCG $\beta c f$ had a molar concentration of approximately $25 \%$ of that of intact hCG, and its levels were significantly elevated (approximately 60\%) in the tissue extracts of the same samples that were used for the organ culture. This may indicate that, besides direct release, hCG $\beta c f$ could be retained in the tissue by local degradation of intact hCG or free hCG $\beta$ produced by the syncytiotrophoblast. The result from immunohistochemical staining of molar tissue, which showed that the stromal cells as well as the syncytiotrophoblasts were positive for hCG $\beta c f$, supports this hypothesis. With respect to choriocarcinoma, the immunohistochemistry showed that the syncytiotrophoblastic cells were mainly positive for hCG $\beta c f$. In our previous report (Okamoto et al. 2001), the hCG $\beta \mathrm{cf} / \mathrm{hCG}$ ratio in the culture medium of NaUCC-3 choriocarcinoma cells in vitro was $11 \%$, while the present study showed that the ratio increased to $316 \%$ in the extract of the tumor formed by the inoculation of the same cells into a nude mouse, and similar levels were also observed in the extracts of the other clinical specimens of choriocarcinoma (Table 2). Thus, it seems likely that the presence of stromal tissue could promote production of hCG $\beta c f$ through local degradation of hCG or free hCG $\beta$ in gestational trophoblastic tumors.

Previously, we reported that the major form of hCG $\beta \mathrm{cf}$ immunoreactivity secreted by cancer cells in vitro was larger than the standard hCG $\beta c f$, possibly a trimer of hCG $\beta$ cf (Okamoto et al. 2001), which was compatible with the intrinsic characteristic of hCG $\beta c f$ that polymerization could occur when it exists in high concentration in solution (Cole et al. 1999). On the other hand, the present study demonstrated that the size of the major immunoreactivity of hCG $\beta c f$ in the tumor formed by NaUCC-3 choriocarcinoma cells as well as in a clinical specimen of choriocarcinoma was identical to that of the standard urinary hCG $\beta$ cf (Fig. 3). This result suggests that, even though polymerization of the hCG $\beta$ cf molecule may occur, aggregated forms of hCG $\beta$ cf could be degraded into the monomer when cancer cells exist in vivo, possibly by local degradation. 
Table 3 Serum levels of hCG, free hCG $\beta$, and hCG $\beta$ cf in the patients with GTD

\begin{tabular}{|c|c|c|c|c|c|}
\hline & $\begin{array}{l}\text { hCG } \\
(\mathrm{pmol} / \mathrm{ml})\end{array}$ & $\begin{array}{l}\text { Free } \beta \\
(\mathrm{pmol} / \mathrm{ml})\end{array}$ & $\begin{array}{l}\text { hCGßcf } \\
(\mathrm{pmol} / \mathrm{ml})\end{array}$ & $\begin{array}{l}\text { Free } \beta / \text { hCG } \\
(\%)\end{array}$ & $\begin{array}{l}\text { hCGßcf/hCG } \\
(\%)\end{array}$ \\
\hline \multicolumn{6}{|l|}{ Patient } \\
\hline \multicolumn{6}{|l|}{ Mole } \\
\hline 1 & 250 & $5 \cdot 3$ & $0 \cdot 30$ & $2 \cdot 1$ & $0 \cdot 12$ \\
\hline 2 & 219 & $8 \cdot 9$ & $0 \cdot 43$ & $4 \cdot 1$ & $0 \cdot 20$ \\
\hline 3 & 201 & $12 \cdot 1$ & $0 \cdot 37$ & $6 \cdot 0$ & $0 \cdot 18$ \\
\hline 4 & 441 & $38 \cdot 7$ & $1 \cdot 7$ & $8 \cdot 8$ & $0 \cdot 39$ \\
\hline 5 & 47 & 0.73 & 0.07 & $1 \cdot 6$ & $0 \cdot 15$ \\
\hline 6 & 163 & $12 \cdot 3$ & $0 \cdot 45$ & $7 \cdot 5$ & $0 \cdot 28$ \\
\hline 7 & 520 & $28 \cdot 4$ & 0.99 & $5 \cdot 5$ & $0 \cdot 19$ \\
\hline 8 & 872 & $20 \cdot 9$ & $1 \cdot 1$ & $2 \cdot 4$ & $0 \cdot 13$ \\
\hline 9 & 45 & 0.93 & 0.09 & $2 \cdot 1$ & $0 \cdot 20$ \\
\hline $10^{*}$ & 755 & $2 \cdot 9$ & $0 \cdot 83$ & $0 \cdot 38$ & $0 \cdot 11$ \\
\hline $11^{*}$ & 2226 & $19 \cdot 7$ & $0 \cdot 42$ & $0 \cdot 88$ & $0 \cdot 02$ \\
\hline $12^{*}$ & 3755 & $71 \cdot 8$ & $3 \cdot 43$ & 1.9 & 0.09 \\
\hline $13^{*}$ & 371 & $8 \cdot 5$ & $1 \cdot 23$ & $2 \cdot 3$ & $0 \cdot 33$ \\
\hline \multicolumn{6}{|c|}{ Invasive Mole } \\
\hline $10^{*}$ & $2 \cdot 2$ & $0 \cdot 05$ & 0.014 & $2 \cdot 3$ & $0 \cdot 64$ \\
\hline $11^{*}$ & 113 & $2 \cdot 6$ & 0.073 & $2 \cdot 3$ & 0.06 \\
\hline $12^{*}$ & 120 & $5 \cdot 4$ & $0 \cdot 24$ & $4 \cdot 5$ & $0 \cdot 20$ \\
\hline $13^{*}$ & $12 \cdot 8$ & $0 \cdot 39$ & 0.056 & $3 \cdot 0$ & $0 \cdot 44$ \\
\hline 14 & $2 \cdot 7$ & $0 \cdot 04$ & 0.019 & $1 \cdot 5$ & $0 \cdot 70$ \\
\hline \multicolumn{6}{|c|}{ Choriocarcinoma } \\
\hline 15 & $0 \cdot 38$ & $0 \cdot 03$ & 0.005 & $7 \cdot 9$ & $1 \cdot 31$ \\
\hline 16 & $2 \cdot 17$ & $0 \cdot 18$ & 0.006 & $8 \cdot 3$ & $0 \cdot 28$ \\
\hline 17 & $1 \cdot 04$ & $0 \cdot 44$ & 0.013 & $42 \cdot 3$ & $1 \cdot 25$ \\
\hline 18 & $1 \cdot 07$ & $0 \cdot 41$ & 0.004 & $38 \cdot 3$ & $0 \cdot 37$ \\
\hline
\end{tabular}

*Patients 10-13 developed persistent GTD (clinical invasive mole) after evacuation of hydatidiform mole.

In contrast to accounting for most of the hCG immunoreactivity in pregnancy urine, hCG $\beta$ cf is present only in minute amounts in pregnancy serum (Alfthan \& Stenman 1990, Wehmann et al. 1990, Udagawa et al. 1998). Little information is currently available regarding concentrations of hCG $\beta c f$ in the serum of patients with GTD, and to the best of our knowledge, the present study is the first to demonstrate the presence of hCG $\beta c f$ immunoreactivity in their serum. Khan et al. (2000) failed to detect hCG $\beta c f$ in the serum of patients with hydatidiform mole. This discrepancy is likely to be due to the difference in the specificity of the antibody against hCG $\beta c f$. The antibody used in their study was not specific to hCG $\beta$ cf, but it cross-reacted 100\% with free hCG $\beta$ (Yoshimura et al. 1994), resulting in reduced ability to discriminate the hCG $\beta \mathrm{cf}$ molecule from hCG $\beta$, especially in the serum, and it seems that their hCG $\beta$ cf assay underestimated the actual hCG $\beta$ cf levels. Also, it is not surprising that using the technique of immunohistochemistry they observed only weak staining for hCG $\beta c f$ in the syncytiotrophoblasts of molar tissue.

We previously showed that the level of hCG $\beta c f$ immunoreactivity was suppressed in pregnancy serum although hCG $\beta$ cf was abundant in the placenta (Udagawa et al. 1998), which is probably due to its short half-life in the serum (less than $5 \mathrm{~min}$ ) as compared with that of intact
hCG (39 h) or free hCG $(4 \mathrm{~h})$ (Wehmann \& Nisula 1979, Wehmann et al. 1989). The present study demonstrated that this is also the case in the serum of patients with GTD. The mean ratio of hCG $\beta$ cf to hCG was $60 \cdot 8 \%$ in the molar tissue while it was $0 \cdot 19 \%$ in the serum of patients with mole. In choriocarcinoma, the mean hCG $\beta \mathrm{cf} / \mathrm{hCG}$ ratio was $509 \%$ in the tissue while it was $0.84 \%$ in the serum. Thus, the hCG $\beta c f / h C G$ ratio in the serum was reduced to less than one hundredth of that in the tissue. As compared with normal pregnancy, the hCG $\beta c f / h C G$ ratio in the serum of the patients with mole was comparable to that in pregnancy serum $(0 \cdot 10 \%-$ 0.19\%) (Udagawa et al. 1998), and the ratio was elevated in choriocarcinoma. The increased hCG $\beta$ synthesis in choriocarcinoma seems to contribute to this phenomenon; the ratio of free hCG $\beta$ to intact hCG in the tissue was significantly higher in choriocarcinoma than in mole (Table 2), and that ratio in the serum was also elevated in choriocarcinoma (Table 3). Consistent with these data, Ozturk et al. (1988) reported that, during normal pregnancy, the serum free hCG $\beta / \mathrm{hCG}$ ratio remained constant at approximately $0.5 \%$ after 5 weeks of gestation, while serum free hCG $\beta$ levels were elevated in the patients with GTD, reaching more than $5 \%$ of hCG in choriocarcinoma cases. 
(A)

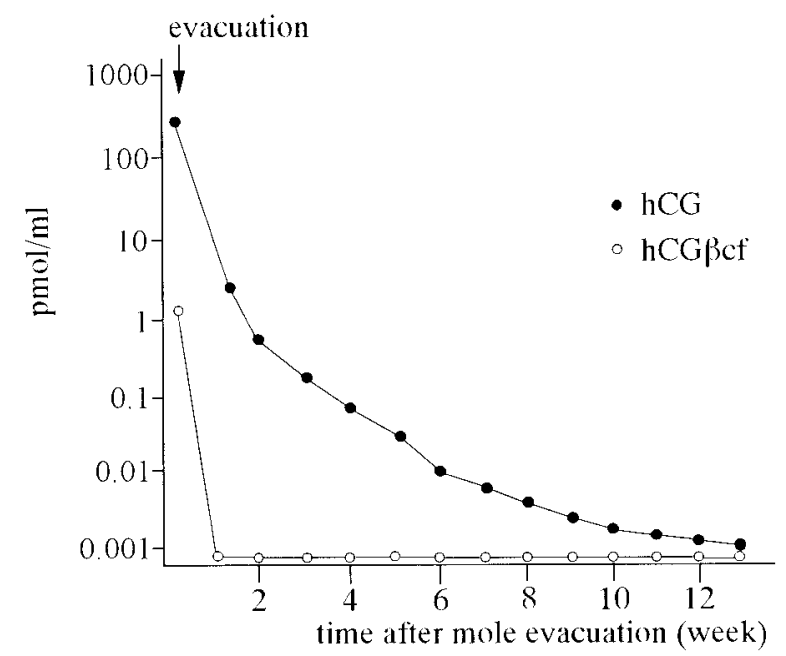

(B)

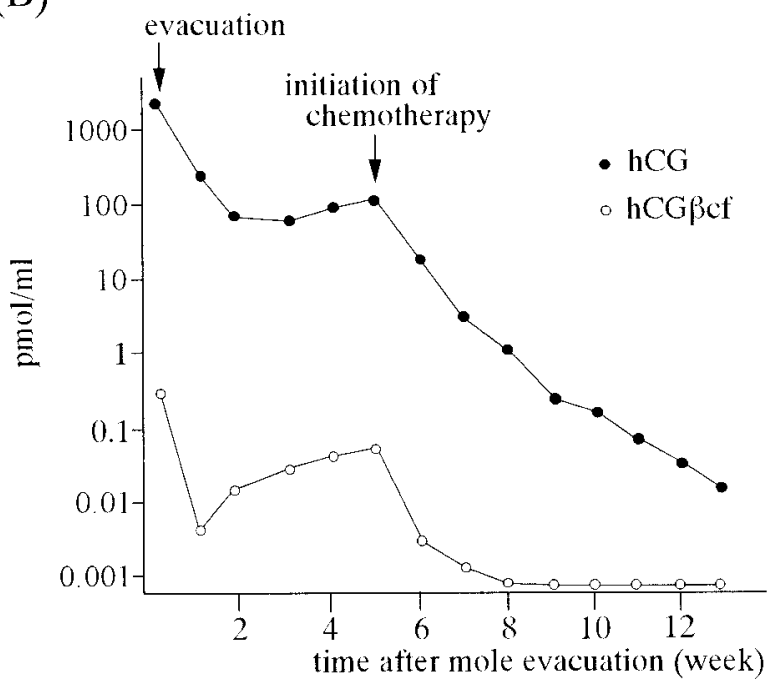

Figure 5 Serum hCG $\beta c f$ levels in the patients with hydatidiform mole after mole evacuation. (A) A patient (no. 4 in Table 3) with subsequent spontaneous remission. (B) A patient (no. 11 in Table 3) with subsequent persistent GTD.

Serum hCG levels are usually extremely elevated, occasionally exceeding $1000000 \mathrm{mIU} / \mathrm{ml}$ (corresponding to approximately $3000 \mathrm{pmol} / \mathrm{ml}$ ), in the patients with hydatidiform mole at the time of mole evacuation and, due to its long circulating half-life, its levels gradually decrease after mole evacuation. Therefore, a relatively small amount of hCG secreted by the persistent trophoblasts may be masked by a large amount of remaining, circulating hCG derived from the evacuated molar tissue, resulting in a time lag before the rise of hCG levels becomes clinically manifest. Follow-up with assessment of hCG levels alone is thus often lengthy, requiring weeks or months to rule out persistent postmolar GTD. The present study showed that, due to its short half-life, serum hCG $\beta c f$ levels rapidly declined and became undetectable after uterine evacuation in the patients with hydatidiform mole with subsequent spontaneous resolution, while they remained elevated or started to rise before persistent GTD was diagnosed based on the rise of hCG levels. This means that detection of hCG $\beta c f$ in the serum after mole evacuation may reflect persistence of viable trophoblasts more sensitively than hCG. On the other hand, once the chemotherapy was initiated, hCG $\beta$ cf became undetectable more rapidly than hCG because of its relatively low levels in the serum and rapid clearance from the circulation as compared with hCG. Therefore, it seems that hCG $\beta$ cf measurement may not be suitable for the follow-up of the patients receiving chemotherapy. Several indicators of high risk for persistent postmolar GTD have been proposed such as markedly elevated hCG levels, uterine size larger than gestational age, the presence of large theca lutein cysts (Curry et al. 1975), or the use of radiological methods (Kohorn et al. 1998), but the detection of any of these risk factors does not ensure the diagnosis of persistent GTD. Considering that, at present, measurement of hCG remains the most reliable means of identifying persistent postmolar GTD, monitoring of hCG $\beta c f$ in the management of patients with hydatidiform mole merits further investigation.

\section{References}

Alfthan H \& Stenman U-H 1990 Pregnancy serum contains the $\beta$-core fragment of human choriogonadotrophin. Journal of Clinical Endocrinology and Metabolism 70 783-787.

Birken S, Armstrong EG, Kolks MAG, Cole LA, Agosto GM, Krichevsky A, Vaitukaitis JL \& Canfield RE 1988 Structure of the human chorionic gonadotropin $\beta$-subunit fragment from pregnancy urine. Endocrinology 123 572-583.

Blithe DL, Akar AH, Wehmann RE \& Nisula BC 1988 Purification of $\beta$-core fragment from pregnancy urine and demonstration that its carbohydrate moieties differ from those of native human chorionic gonadotropin- $\beta$. Endocrinology 122 173-180.

Cole LA \& Birken S 1988 Origin and occurrence of human chorionic gonadotropin $\beta$-subunit core fragment. Molecular Endocrinology 2 825-830.

Cole LA, Rinne KM, Mahajan SM, Oz UA, Shahabi S, Mahoney MJ \& Bahado-Singh RO 1999 Urinary screening tests for fetal Down syndrome: I. Fresh $\beta$-core fragment. Prenatal Diagnosis 19 340-350.

Curry SL, Hammond CB, Tyrey L, Creasman WT \& Parker RT 1975 Hydatidiform mole: diagnosis, management and long-term follow-up of 347 patients. Obstetrics and Gynecology 45 1-8.

Kardana A, Taylor ME, Southall PJ, Boxer GM, Rowan AJ \& Bagshawe KD 1988 Urinary gonadotrophin peptide - isolation and purification, and its immunohistochemical distribution in normal and neoplastic tissues. British Journal of Cancer 58 281-286.

Kato Y \& Braunstein D $1988 \beta$-core fragment is a major form of immunoreactive urinary chorionic gonadotropin in human pregnancy. Journal of Clinical Endocrinology and Metabolism 66 1197-1201.

Khan S, Katabuchi H, Araki M, Ohba T, Koizumi T, Okamura H \& Nishimura R 2000 The molar vesicle fluid contains the $\beta$-core fragment of human chorionic gonadotropin. Placenta 21 79-87.

Kohorn EI, McCarthy SM \& Taylor KJW 1998 Nonmetastatic gestational trophoblastic neoplasia: the role of ultrasonography and 
magnetic resonance imaging. Journal of Reproductive Medicine $\mathbf{4 3}$ 14-20.

Krichevsky A, Birken S, O'Connor J, Bikel K, Schlatterer J, Chen YI, Agosto G \& Canfield R 1991 Development and characterization of a new, highly specific antibody to the human chorionic gonadotropin- $\beta$ fragment. Endocrinology 128 1255-1264.

Lefort GP, Stolk JM \& Nisula BC 1984 Evidence that desialylation and uptake by hepatic receptors for galactose-terminated glycoproteins are immaterial to the metabolism of human choriogonadotropin in the rat. Endocrinology 115 1551-1557.

Lefort GP, Stolk JM \& Nisula BC 1986 Renal metabolism of the $\beta$-subunit of human choriogonadotropin in the rat. Endocrinology 119 924-931.

Lurain JR, Brewer JI, Torok EE \& Halpern B 1983 Natural history of hydatidiform mole after primary evacuation. American Journal of Obstetrics and Gynecolgy 145 591-595.

de Medeiros SF, Amato F, Matthews CD \& Norman RJ 1992 Urinary concentrations of beta core fragment of hCG throughout pregnancy. Obstetrics and Gynecology 80 223-228.

de Medeiros SF, Amato F, Matthews CD \& Norman RJ 1993 Molecular heterogeneity of the $\beta$-core fragment of human chorionic gonadotrophin. Journal of Endocrinology 139 519-532.

Norman RJ, Buchholz M-M, Somogyi AA \& Amato F 2000 hCG $\beta$ core fragment is a metabolite of hCG: evidence from infusion of recombinant hCG. Journal of Endocrinology 164 299-305.

Okamoto T, Nomura S, Nakanishi T, Goto S, Tomoda Y \& Mizutani M 1998 Choriocarcinoma diagnostic score: a scoring system to differentiate choriocarcinoma from invasive mole. International Journal of Gynecological Cancer 8 128-132.

Okamoto T, Niu R, Matsuo K, Furuhashi M, Ohsawa M, Mizutani S \& Suzuki H 2001 Human chorionic gonadotropin $\beta$-core fragment is directly produced by cancer cells. Life Sciences $\mathbf{6 8} 861-872$.

Ozturk M, Berkowitz R, Goldstein D, Bellet D \& Wands JR 1988 Differential production of human chorionic gonadotropin and free subunits in gestational trophoblastic disease. American Journal of Obstetrics and Gynecology 158 193-198.

Sugiura M, Goto S, Saito M, Kato S, Hattori S \& Tomoda Y 1988 Establishment and characterization of three new human gestational choriocarcinoma cell lines. Acta Obstetrica et Gynaecologica Japonica 40 1447-1454.

Udagawa A, Okamoto T, Nomura S, Matsuo K, Suzuki H \& Mizutani S 1998 Human chorionic gonadotropin $\beta$-core fragment is present in the human placenta. Molecular and Cellular Endocrinology 139 171-178.

Wehmann RE \& Nisula BC 1979 Metabolic clearance rates of the subunits of human chorionic gonadotropin. Journal of Clinical Endocrinology and Metabolism 48 753-759.

Wehmann RE \& Nisula BC 1980 Characterization of a discrete degradation product of the human chorionic gonadotropin $\beta$-subunit in humans. Journal of Clinical Endocrinology and Metabolism 51 101-105.

Wehmann RE, Blithe DL, Flack MR \& Nisula BC 1989 Metabolic clearance rate and urinary clearance of purified $\beta$-core. Journal of Clinical Endocrinology and Metabolism 69 510-517.

Wehmann RE, Blithe DL, Akar AH \& Nisula BC 1990 Disparity between $\beta$-core levels in pregnancy urine and serum: implications for the origin of urinary $\beta$-core. Journal of Clinical Endocrinology and Metabolism 70 371-378.

Yoshimura M, Nishimura R, Murotani A, Miyamoto Y, Nakagawa T, Hasegawa K, Koizumi T, Shii K, Baba S \& Tsubota N 1994 Assessment of urinary $\beta$-core fragment of human chorionic gonadotropin as a new tumor marker of lung cancer. Cancer $\mathbf{7 3}$ $2745-2752$.

Received 5 April 2001

Accepted 21 August 2001 